\title{
Romiešu sabiedrības līgums (societa) un romiešu tiesiskie principi mūsdienu Latvijas tiesībās
}

\author{
Allars Apsītis \\ Rīgas Stradiña universitāte, Latvija \\ allars@inbox.lv
}

\section{Kopsavilkums}

Rakstā atspoguḷoti autora veiktās romiešu tiesību pirmavotu, galvenokārt romiešu sabiedrības līguma (societa - lat. val.), tiesiskā regulējuma izpētes rezultāti par minētā regulējuma un modernās Latvijas likumdošanas aktu idejiskajām kopsakarībām. Tajā uzsvērta romiešu legālo principu ietekme uz tādu darījumu, kuru priekšmets ir neatḷauta un nepieklājīga darbība ar reliǵijai, likumiem vai labiem tikumiem pretēju mērḳi, spēkā neesamības tiesiskajā reglamentācijā, kā arī uz Latvijas Republikas Civillikumā ietverto "maldỉbas", "viltus", "nosacijumu", "termiṇu" un "tiesiska darījuma formas" koncepciju romiskajiem pamatiem. Latvijas pētnieki minēto tematiku šādā skatupunktā īpaši nav aplūkojuši, ar publikācijām latviešu valodā autoram saskarties nav nācies, tāpēc šis pētījums varētu dot ieguldỉjumu nacionālās tiesību zinātnes attīstībā.

Atslēgvārdi: Civillikums, romiešu civiltiesības, sabiedrības līgums.

\section{levads}

Pētījums tapis kā atsevišķs darbs no autora realizētā romiešu privāttiesību pirmavotu pētījuma, kas veikts promocijas darba "Kapitāla apvienošana romiešu tiesībās un to ietekme uz mūsdienu Latvijas Republikas tiesību institūtiem" tapšanas gaitā. Saskaņā ar autora rīcībā esošo informāciju Latvijas pētnieki minēto tematiku šādā skatupunktā īpaši nav aplūkojuši, ar publikācijām latviešu valodā autoram saskarties nav nācies. Tādējādi, pētījums varētu dot zināmu ieguldỉjumu nacionālās tiesību zinātnes attīstībā. 
Allars Apsìtis. Romiešu sabiedrības (societa) līgums un romiešu tiesiskie principi mūsdienu Latvijas tiesībās

\section{Darba mērkis}

Šì darba mērḳis bija izpētìt romiešu tiesību pirmavotos rodamo informāciju par sabiedrības līguma tiesiskās reglamentācijas īpatnībām un veikt romiešu tiesību pirmavotu un modernās Latvijas likumdošanas aktu idejisko kopsakarību analīzi.

\section{Materiāls un metodes}

Pētījuma gaitā realizēta romiešu tiesību pirmavotu (Codex Iustinianus, Digesta, Iustiniani Institutiones) un mūsdienu Latvijas Republikas likumdošanas aktu izpēte un analīze, izmantojot induktīvo, deduktīvo un salīdzinošo metodi.

\section{Rezultāti un diskusija}

Seno romiešu civilizācijas ietvaros tika izveidota visai sarežğìta un l̦oti veiksmīga tiesiskā bāze, lai liela un tam laikam augsti attīstīta impērija varētu sekmīgi funkcionēt. Tāpat nepieciešams norādìt, ka romiešu radìtie tiesiskie principi, ỉpaši privāto jeb civiltiesību jomā, ir izrādījušies tik veiksmīgi, ka joprojām atrodas Rietumu un nu jau arī visas globalizētās pasaules privāto tiesību pamatā. Vietām šì ietekme ir tiešāka kontinentālajā Eiropā un tās valstu bijušajās kolonijās pastāvošā t. s. romāṇu-ǵermāṇu jeb kontinentālās Eiropas tiesību sistēma, vietām vairāk pastarpināta - Anglijā un Velsā, ASV un lielākajā dạ̦ā bijušo britu koloniju izplatītā anglosakšu jeb vispāāējo tiesību sistēma. Mūsdienu Latvija pieder kontinentālās Eiropas tiesību sistēmai, un seno romiešu iedibinātie principi, tiesību normu recepcijas vēsturiskās attīstības gaitā pārṇemtas arī Latvijas Republikas normatīvajos aktos.

Minētais vērojams, aplūkojot romiešu sabiedrības līguma tiesisko regulējumu. Tā, piemēram, romiešu tiesību pirmavotos norādīts, ka visi romiešu sabiedrības līgumus reglamentējošie noteikumi attiecas vienīgi uz situācijām, kad sabiedrība veidota cienījamu un likumīgu mērḳu sasniegšanai. Ja sabiedrība radīta ar nolūku pārkāpt likumu, sabiedrības līgums ir spēkā neesošs, jo tolaik bija vispārpieṇemts, ka sabiedrības līguma lietās nevar būt kas tāds, kas ir apkaunojošs (D 17.2.57) [3, 342]. Jebkāda veida noziedzīgi nolūki nozīmēja sabiedrības līguma automātisku spēkā neesamību.

Bija noteikts, ka nav iespējama sabiedrība, kas kopēji iepirktu nāvējošu indi. Minētais attiecās uz visām vielām, kuras pat pēc atbilstošu papildelementu pievienošanas nebija padarāmas par lietošanai derīgām. Turpretī, ja indīgās vielas bija izmantojamas farmācijā vai pretinžu izgatavošanai paredzētos maisījumos, to kopējas iegādes realizēšanai varēja tikt noslēgts sabiedrības līgums (D 18.1.35.2) [3, 348].

Tāpat par likumīgu un puses legāli saistošu sabiedrību nebija atzīstama personu apvienība kopīgai zādzības (furtum - lat. val.) pastrādāšanai. Tādējādi zagḷu bandas dalïbnieki nevarēja celt savstarpējus prasījumus par kaut kādu panākto vienošanos neizpildi. Piemēram, zag̣̣i nevarēja būt viens otra galvinieki (fideiussores - lat. val.), 
Allars Apsìtis. Romiešu sabiedrības (societa) līgums un romiešu tiesiskie principi mūsdienu Latvijas tiesībās

lai piek̦eršanas gadījumā samaksātu piespriesto soda naudu. Vienošanās par šādu galvojumu (fideiussio - lat. val.) bija spēkā neesoša un dalībniekus legāli nesaistoša (D 46.1.70.5) [3, 867].

Līdzīgi bija gadījumā, ja aizbildni (tutor - lat. val.) kopā ar citiem līdzaizbildṇiem pieķēra aizbilstamā mantas izsaimniekošanā. Tad piespriestā soda nauda pašam arī bija jānomaksā un no līdzdalībniekiem to ne pilnībā, ne daḷēji piedzìt nevarēja. Jo, lai kādas arī savulaik būtu bijušas aizbildṇu savstarpējās vienošanās, sabiedrības nozieguma pastrādāšanai (societas maleficiorum - lat. val.) likums neatzina (D 27.3.1.14) [3, 483].

Turklāt par nelikumīgām sabiedrībām uzskatīja arī apvienības viltotu pierādījumu fabricēšanai, viltus liecinieku piesaistei, testamentu viltošanai, liecinieku uzpirkšanai un nepamatotu tiesas procesu izraisišanai par samaksu (D 48.10 .1 pr.) [3, 937].

Iepriekšminētās romiešu iedibinātās legālās tradīcijas pilnā mērā atspoguḷojas Latvijas Civillikumā. Tādējādi par tiesiska darījuma, tostarp sabiedrības līguma, priekšmetu nevar būt neatḷauta un nepieklājīga darbība, kuras mērḳis ir pretējs religijai, likumiem vai labiem tikumiem vai kura vērsta uz to, lai apietu likumu. Šãds darījums ir spēkā neesošs [6, CL 1415. p.]. Tāpat Civillikumā norādìts, ka neviens līgums, kas veicina kaut ko pretlikumīgu, netikumīgu vai negodīgu, nesaista. Ja viena puse ar viltu piedabūta šãdu līgumu noslēgt, tai ir tiesības prasìt zaudējumu atlīdzību [6, CL 1592.p.].

Līdzīgi varam runāt par maldības koncepcijas pārṇemšanu. Romiešu sabiedrības līgums bija tā sauktais konsensuālkontrakts - tika uzskatīts par noslēgtu ar brīdi, kad puses panākušas attiecīgo vienošanos (Consensu fiunt obligationes in... societatibus... lat. val.), savukārt to izpildīt varēja arī vēlāk (D 44.7 .2 pr.) [3, 847]. Turklāt bija svarīgi, lai vienošanās tiešām atspoguḷotu pušu patiesos nolūkus un nodomus un lai visi sabiedrības biedri vienādi un nepārprotami izprastu, par ko galu galā vienojušies. Ja vienošanās nepauda biedru patieso un ìsteno gribu, tā varēja tikt uzskatīta par spēkā neesošu (D 44.7.57) [3, 851].

Šāda veida romiskas izcelsmes legāla tradīcija pārṇemta arī Latvijas Civillikumā, kur paredzēta nepieciešamība pēc tiesiska darījuma dalībnieku (starp citu, arī mūsdienu sabiedrības līguma slēdzēju) brīvas gribas izteikuma. Tiesiska darījuma spēkā esamībai vajadzīgs, lai dalībnieku griba būtu brīvi radusies, turklāt bez maldības $[6, C L$ 1440. $p]$. Ja maldība atzīstama par svarīgu (piemēram, maldība par darìjuma šḳiru [6, CL 1447. p.], lietas identitāti [6, CL 1448. p.] vai kādu personu darijumā - ja vien personu maiña ir nozīmīga tam, kas maldỉjies, vai, ja maldỉba attiecas uz kāda personiskām spējām un īpašỉbām un maldīgi pieņemtā īpašỉba pēc darījuma rakstura ir svarīga [6,CL 1450. p. u. c.]), tā iznīcina visu darījuma spēku, “...jo jāpieņem, ka tas, kas tā maldījies, nav nemaz devis darījumam savu piekrišanu un darījums tātad nemaz nav noticis" [6, CL 1445. p.].

Arī Latvijas Civillikumā ietvertā doma par viltu kā otras personas prettiesīgu maldinājumu, lai piedabūtu šo personu veikt kādu tās interesēm pretēju darbību vai atturēties no darbības veikšanas [6, CL 1459. p.], uzskatāma par romiešu legālo mantojumu. 
Allars Apsìtis. Romiešu sabiedrības (societa) līgums un romiešu tiesiskie principi mūsdienu Latvijas tiesībās

Ja romiešu sabiedrības līgumu noslēdza ar viltu vai nolūkā veikt viltīgas darbības, to uzskatīja par spēkā neesošu, jo viltus un blēdīšanās ir pretrunā ar labas ticības principiem (Societas si dolo malo aut fraudandi causa coita sit, ipso iure nullius momenti est, quia fides bona contraria est fraudi et dolo - lat. val.) (D 17.2.3.3) [3, 339].

Ar viltu (dolus - lat. val.) tika saprasta tīša un apzināta maldināšana - viltība, blēdība, krāpšana, mahinācija, lai otru apmānītu vai piemuḷ ķotu tā, lai piedabūtu viṇu rīkoties pretēji savām interesēm (D 4.3.1.2). Piemēram, noslēgt neizdevīgu līgumu vai pieņemt maksātnespējīgas personas atstātu mantojumu pārliecībā, ka tas ir ar parādiem neapkrauts. Tika īpaši norādīts, ka šeit domāts viltus l̦aunā nolūkā (dolus malus lat. val., - "sliktais viltus"), kuru nepieciešams atškirt no viltus, kas pastrādāts ar labiem nolūkiem (dolus bonus - lat. val., - "labais viltus"), piemēram, lai maldinātu ienaidnieku vai laupitāju (D.4.3.1.3) [3, 166] (vairāk par viltu sk.: D 4.3 tit. [3, 165-168]).

Romiešu juristu izstrādātais labas ticības (bona fides - lat. val.) princips ir uzskatāms ne tik vien par juridisku, bet arī par morāli ètisku kategoriju, kura, starp citu, tiek atzīta par vienu no mūsdienu juridiskās ētikas pamatelementiem. Saskan̄ā ar romiešu juristu priekšstatiem personas (kontrahenta, lietas valdītāja u. c.) rīcība un darbības nedrīkstēja saturēt nekādus viltus un netaisnības elementus. Turklāt nebija svarīgi, vai viltus izpaudies kā aktīva darbība vai kā pasīva atturēšanās no darbības [5, 207].

Bija svarīgi pierādīt personas pārliecību, ka viṇas rīcībā tiešām nav viltus vai launprātības elementu. Tā, piemēram, par lietas labticīgu valdītāju tika uzskatīts tāds, kurš varēja pierādīt, ka tiešām bijis pārliecināts, ka viṇam un tikai viṇam ir vislielākās tiesības uz lietas valdī̌sanu un vinšs tiešām nav zinājis, ka iegādājies zagtu mantu (I 2.6. pr.; I 2.6.1-2) [4, 37], bet domājis, ka pērk to no îpašnieka vai no tāda, kam ir tiesības mantu atsavināt, - personas likumīga pārstāvja vai aizbildṇa (viňš ir bonae fidei emptor - lat. val., - "pircējs labā ticībā") (D 50.16.109) [3, 996]. Zaglis savukārt uzskatāms par l̦aunprātīgu valdītāju, jo, neapšaubāmi, zina, ka valda pār mantu, ko pats nozadzis (I 2.6.3) [1, 12].

Tādējādi, ja, piemēram, kāds nepilngadīgais (minor - lat. val., 14-25 g. v.) ar viltus palīdzību bija piedabūts noslēgt sabiedrības līgumu vai sabiedrības līgumu dāvināšanas nolūkā (donationis causa - lat. val.), juridiski šāds līgums neeksistēja (D 4.4.16.1) [3, 171].

Mūsdienu Latvijas likumdošanā vērojama dạ̦ēja atkāpšanās no minētā principa - saskaņā ar Civillikumu pieviltajam ir tiesības prasìt darỉjuma atcelšanu, bet par spēkā neesošu to tomēr neuzskata. Darījums nav spēkā neesošs, tomēr ir apstrīdams tas, kas ar viltu piedabūts noslēgt darījumu, var prasìt, lai to atceḷ. Turklāt, ja viltus bijis par iemeslu tikai dažiem darijuma noteikumiem, pieviltajam ir tiesības prasit tikai zaudējumu atlīdzību [6, CL 1461. p.].

Ja vien pastāvēja šāda vēlme vai vajadzība, romiešu sabiedrības līguma spēkā esamību varēja padarīt atkarīgu no kāda nosacījuma izpildes. Romiešu juristi sākotnēji gan esot šaubïjušies, vai sabiedrību var dibināt, paredzot īpašus noteikumus. Piemēram, vai sabiedrības līgumā var paredzēt, ka tas kḷutu biedriem saistošs vienīgi 
Allars Apsìtis. Romiešu sabiedrības (societa) līgums un romiešu tiesiskie principi mūsdienu Latvijas tiesībās

gadījumā, ja kāda persona tiktu ievēlēta valsts amatā - kḷūtu par konsulu. Visbeidzot, imperators Justiniāns noteica, ka biedriem ir tiesības veidot sabiedrības gan bez (pure - lat. val., - "tīri"), gan ar nosacījumiem, "lai nākotnē nekādas veco laiku šaubas nerastos", jo visādā ziṇā esot ṇemamas vērā personu vēlmes slēgt likumīgus līgumus (C 4.37.6) [2, 207].

Līgumslēdzēju tiesības uz dažādu blakus noteikumu, tostarp nosacījumu, ieviešanu katrā līgumā saskaṇā ar romiešu iedibinātu tradīciju garantē arī Latvijas Civillikums [6, CL 1548. p.]. Ar nosacijumu tiek saprasts tāds blakus noteikums, ar kuru līguma spēks darīts atkarīgs no kāda nākoša un nezināma vai vismaz par tādu domājama notikuma [6, CL 1549. p.]. Ja ar nosacijjumu nosacìts līguma spēka sākums, to dēvē par atliekošu nosacijumu [6, CL 1551. p.].

Romiešu sabiedrība varēja tikt veidota kā uz noteiktu termiṇu, tā uz sabiedrības biedru dzīves laiku - bez darbības termiņa ierobežojuma.

Noslēgtais sabiedrības līgums varēja stāties spēkā kā nekavējoši, tā iestājoties kādam noteiktam termiṇam vai kādiem noteiktiem apstākḷiem (D 17.2.1. pr.) [3, 339].

Balstoties uz romiskajiem legālajiem principiem, Latvijas Republikas Civillikumā noteikts, ka mūsdienu sabiedrības līguma ilgumu var aprobežot ar noteiktu laiku. Tāpat iespējama sabiedrības līguma noslēgšana uz nenoteiktu laiku [6, CL 2242. p.]. Turklāt Latvijas Civillikums nosaka, ka katrā līgumā, tātad arī sabiedrības līgumā, var ieviest nosacijumus un terminus [6, CL 1548. p.], tostarp atliekošus nosacỉjumus, ar kuriem nosacìts līguma spēka sākums [6, CL 1551. p.], un sākuma termiṇus, kas no līguma izrietošās tiesības sākumu dara atkarīgu no zināma brǐža iestāšanās [6, CL 1579. p.].

Latvijas Komerclikums savukārt paredz, ka attiecībā uz pilnsabiedrību / komandìtsabiedrību pieñemams, ka par sabiedrību, kas nodibināta uz nenoteiktu laiku, uzskatāma arī tāda sabiedrība, kas nodibināta uz laiku līdz kāda sabiedrības biedra mūža beigām [7, KoL 100. p. 1].

Tīri tehniski romiešu sabiedrības līgumu varēja noslēgt vairākās formās ar mantas ieguldišanu, mutvārdos vai ar ziṇneša starpniecību (D 17.2.4 pr.) [3, 339]. Tāpat vienošanās faktu bija iespējams dokumentēt rakstveida līgumā (D 44.7.2.1), kā arī apmainoties ar rakstiskām vēstulēm (D 44.7.2.2) [3, 847].

Jebkurā gadījumā rakstiskai formai acīmredzot bija zināmas priekšrocības. No tiesību avotiem noprotams, ka privātā kārtā taisītiem aktiem (idiochira - gr. val.), tostarp arī aktiem par sabiedrības līgumiem, ja vien tie bija rakstiski sastādīti, parasti tika piešķirts publiski taisìtu dokumentu statuss (quasi publice scriptas - lat. val.). Minētais vajadzỉbas gadījumā jūtami atviegloja attiecīgā prasỉjuma celšanas un faktu pierādīšanas iespējas (C 8.17.11 pr.) [2, 373].

Romiešu aizsākto tradīciju ietekmē Latvijas Civillikums piel̦auj tiesiska darījuma taisītāja gribas izteikumu arī ar darbībām, kas uzskatāmas par klusējot izdarītu gribas izteikumu (t. s. konkludentās darbības), - šìm darbībām jābūt tādām, no kurām var droši secināt gribas esamību. Tāpat gribu var izteikt noteikti - ar vārdiem, mutiski 
Allars Apsītis. Romiešu sabiedrības (societa) līgums un romiešu tiesiskie principi mūsdienu Latvijas tiesībās

vai rakstiski [6, CL 1428. p.]. Papildus jānorāda, ka noteikti gribu var izteikt ar zīmēm, kam ir vārdu nozīme [6, CL 1428. p.], un klusējot, bez konkludentu darbību veikšanas ìpašos gadijumos, kad likums tieši pieprasa pārtraukt klusēšanu, lai to neatzītu par piekrišanu [6, CL 1428. p.; CL 1430. p.].

Kopumā tiesiska darījuma formas izvēle atstāta pašu lietas dalībnieku ieskatam, izṇemot likumā īpaši norādìtus gadījumus [6, CL 1473. p.].

Runājot tieši par sabiedrības līguma formas regulējumu, - Civillikums to atsevišķi nereglamentē, formas izvēli atstājot pašu līgumslēdzēju zin̦ā [6, sk. CL 2241. p.CL 2280. p]. Tas pats sakāms arī par Komerclikuma kā speciālā likuma regulējumu attiecībā uz sabiedrības līguma formu pilnsabiedrībās / komandītsabiedrībās [7, sk. KoL 77. p.-KoL 133. p.]. Tādējādi teorētiski šeit, līdzīgi kā Senajā Romā, iespējama sabiedrības līguma noslēgšana, piemēram, mutvārdos vai ar mantas ieguldīšanas - konkludentu darbību - palīdzību. Tomēr, nnemot vērā apstākli, ka saskaṇā ar Latvijas Civillikumu darījuma rakstiska forma atškirīibā no romiešu prakses ir obligāts nosacījums, piemēram, prasības tiesībai uz darījuma pamata [6, CL 1483. p. 4)], šāda sabiedrības biedru rīcība diez vai būtu uzskatāma par lietderīgu. Tāpat no lietderības un faktu pierādīšanas viedokḷa būtu novērtējams apstāklis, ka tieši rakstiska akta parakstī̌̌ana uzskatāma par pierādījumu parakstītāja piekrišanai aktam, ja tā saturs parakstītājam bijis zināms un ja viṇam tiesiskā darījumā, uz kuru akts attiecas, ir personīga interese un ierunas tiesība [6, CL 1431. p.].

\section{Secinājumi}

Kopumā secināms - seno romiešu iedibinātie legālie principi, līdzīgi kā citās kontinentālās Eiropas tiesību zemēs, raduši pielietojumu arī Latvijas Republikas likumdošanā. Minētais fenomens uzskatāms par romiešu aizsākto tiesisko tradīciju recepcijas un turpmākas attīstības rezultātu un vērojams, pētot romiešu tiesību pirmavotus par sabiedrības lïguma tiesisko regulējumu.

Romisko principu ietekme saskatāma, piemēram, Latvijas Civillikuma specifiskajās normās, kas pasludina par spēkā neesošiem tādus darījumus, kuru priekšmets ir neatḷauta un nepieklājīga darbība ar religijai, likumiem vai labiem tikumiem pretēju mērḳi, vai darbība, kas vērsta uz likuma apiešanu (D 17.2.57; D 18.1.35.2; D 46.1.70.5; D 27.3.1.14; D 48.10 .1 pr. vs CL 1415. p.; CL 1592. p.).

Tāpat Latvijas civiltiesībās pārṇemta romiešu koncepcija par nepieciešamību novērst tiesiska darījuma dalïbnieku maldības (D 44.7 .57 vs CL 1440. p.; CL 1445. p.) un viltus (dolus - lat. val.) pielietošanas (D 4.3.1.2 ; D.4.3.1.3 vs CL 1459. p. / D 17.2.3.3; D 4.4.16.1 vs CL 1461. p.) negatīvo ietekmi.

Lìdzīgi pārṇemti romiešu tiesību principi attiecībā uz līgumos ietveramajiem nosacijumiem (C 4.37.6 vs $C L$ 1548. p.; $C L$ 1549. p.; $C L$ 1551. p.) un terminiem (D 17.2.1. pr. vs CL 1548. p.; CL 1551. p.; CL 1579. p.), tostarp attiecībā uz sabiedrību darbības laika intervāliem (D 17.2.1. pr. vs CL 2242. p.; KoL 100. p. 1). 
Allars Apsìtis. Romiešu sabiedrības (societa) līgums un romiešu tiesiskie principi mūsdienu Latvijas tiesībās

Turklāt Latvijas likumdošana satur romiska rakstura idejas par tiesisku darījumu formām (D 17.2.4 pr. D 44.7.2.1; D 44.7.2.2 vs CL 1428. p.) un rakstiskā formā noslēgtiem tiesiskiem darījumiem piešḳiramajām ỉpašajām priekšrocībām $(C 8.17 .11$ pr. vs $C L$ 1483. p. 4); CL 1431. p.).

Tādējādi seno romiešu tiesiskās kultūras sasniegumi turpina kalpot arī mūsdienu Latvijas Republikas modernās sabiedrības vajadzību nodrošināšanai.

Pètījums tapis kā atsevišks darbs no autora realizètā romiešu privāttiesību pirmavotu pētījuma, kas veikts promocijas darba "Kapitāla apvienošana romiešu tiesībās un to ietekme uz müsdienu Latvijas Republikas tiesību institūtiem" (aizstāvēts 18.08.2015., RSU Juridiskās zinātnes promocijas padomes lēmums) tapšanas gaitā.

\section{Roman Partnership Agreement (Societa) and Roman Legal Principles in the Law of Modern Latvia}

\section{Abstract}

The article deals with the results of the author's research performed on the original sources of the legal regulation of Roman Law, mainly, Roman partnership agreement (societa - Latin) in relation to the principles of interconnections between the above mentioned regulation and the legislative acts of modern Latvia. The influence of Roman legal principles in relation to the regulation of an impermissible or indecent action has been pointed out, the purpose of which is contrary to religion, laws or moral principles - it may not be the subject-matter of a lawful transaction; such a transaction is void; there have also been emphasised such concepts as "mistake", "fraud", "conditions", "terms" and "form of lawful transaction", which are based on the Roman Law and included into the Civil Law of the Republic of Latvia. Latvian researchers have not studied the above mentioned problems in relation to these aspects; the author has not found any publication in Latvian concerning these issues. Thus, the research might be a particular contribution to the development of national jurisprudence.

Keywords: Roman Law, Roman partnership, Civil Law of the Republic of Latvia.

\section{Literatūra}

1. Apsītis, A., Joksts, O. Noziedzīgs nodarījums zādzība (furtum) romiešu tiesību kontekstā. Administratìvā un Kriminālà Justīcija, 2013; 1 (62), ISSN 1407-2971, 12. lpp.

2. Krueger, P. Corpus Iuris Civilis, Editio Stereotypia Octava, Volumen Secundum, Codex Iustinianus, Recognovit Paulus Krueger (Corpus Iuris Civilis, 8. stereotipais izdevums, 2. sējums, Justiniāna Kodekss, redigéejis Pauls Krīgers.) Berlīne: Weidmannos, 1906. 177, 343. Iegūts no: 
Allars Apsītis. Romiešu sabiedrības (societa) līgums un romiešu tiesiskie principi mūsdienu Latvijas tiesībās

http://fama2.us.es/fde/ocr/2007/corpusIurisCivilisCodexIustinianus.pdf, 207, 373 [sk. 05.10.2015.]

3. Krueger, P., Mommsen, T. Iustiniani Digesta. Corpus Iuris Civilis, Editio Stereotypia Quinta Decima, Volumen Primum, Institutiones, Recognovit Paulus Krueger, Digesta, Recognovit Theodorus Mommsen, Retractavit Paulus Krueger. (Justiniāna Digestas. Corpus Iuris Civilis, 15. stereotipais izdevums, 1. sējums, Institūcijas, redigéejis Pauls Krïgers, Digestas, rediǵéjis Teodors Momsens, atkārtoti pārlūkojis Pauls Krīgers.) Berlīne: Weidmannos, 1928, 82-85, 83, 88, 256, 259, 265, 400, 764, 768, 793, 854, 913. Iegūts no: http://fama2.us.es/fde/ocr/2006/ corpusIurisCivilisT1InstitutionesDigesta.pdf, 165-168, 166, 171, 339, 342, 348, 483, 847, 851, 876, 937, 996 [sk. 05.10.2015.].

4. Krueger, P., Mommsen, T. Iustiniani Institutiones. Corpus Iuris Civilis, Editio Stereotypia Quinta Decima, Volumen Primum, Institutiones, Recognovit Paulus Krueger, Digesta, Recognovit Theodorus Mommsen, Retractavit Paulus Krueger (Justiniāna Institūcijas. Corpus Iuris Civilis, 15. stereotipais izdevums, 1. sējums, Institūcijas, redigéejis Pauls Krīgers, Digesta, rediḡéjis Teodors Momsens, atkārtoti pārlūkojis Pauls Krïgers.) Berlīne: Weidmannos, 1928. 14. Iegūts no: http://fama2.us.es/fde/ocr/2006/corpusIurisCivilisT1InstitutionesDigesta.pdf, 37 [sk. 05.10.2015.].

5. Smith, W. A Dictionary of Greek and Roman Antiquities. (Grieku un romiešu antīkäs pasaules vārdnīca) London: John Murray, 1875. P. 207.

6. Civillikums. Ceturtā daḷa. Saistību tiesības. 28.01.1937. likums. Valdìbas Vēstnesis, 46, 26.02.1937. Ar grozijumiem, 01.01.2014. redakcija.

7. 13.04.2000. likums “Komerclikums". Latvijas Vēstnesis, 158/160 (2069/2071), ar grozïjumiem, 04.06.2015. redakcija. 